\title{
Response of Eight Maple Cultivars (Acer spp.) to Soil Compaction and Effects of Two Rates of Pre-plant Nitrogen on Tree Establishment and Aboveground Growth
}

\author{
Barbara A. Fair, James D. Metzger, and James Vent
}

\begin{abstract}
This study assessed soil compaction effects on aboveground growth of maple cultivars, and compared two nitrogen rates applied pre-planting for their influence on establishment and growth of trees planted into compacted soils. Eight commonly used maple cultivars of Acer rubrum and Acer $\times$ freemanii were evaluated. During container production, plants received either 25 or $100 \mathrm{mg} \cdot \mathrm{L}^{-1}$ nitrogen through fertigation twice per day. Trees were planted into non-compacted field plots with a mean bulk density of $1.40 \mathrm{~g} \cdot \mathrm{cm}^{-3}$, or into compacted plots with a mean bulk density of $1.60 \mathrm{~g} \cdot \mathrm{cm}^{-3}$. In 2002, researchers randomly selected half of the compacted plots and applied an additional soil treatment. At the completion of this treatment, mean bulk density was $1.55 \mathrm{~g} \cdot \mathrm{cm}^{-3}$. Trees growing in higher density soils had significantly smaller aboveground biomass measures $(P<0.05)$, than those growing in non-compacted plots. There was a significant difference between cultivars $(P<0.0001)$; for example, 'Celzam' and 'Fairview Flame' had greater aboveground biomass values than other cultivars when grown in compacted soils, but compaction still affected growth. The $100 \mathrm{mg} \cdot \mathrm{L}^{-1}$ nitrogen rate increased leaf dry weight and area, but did not impact height and caliper growth or stem dry weight. Key Words. Acer $\times$ freemanii; Acer rubrum; Compaction; Freeman Maple; Nitrogen Rates; Red Maple; Tree Establishment.
\end{abstract}

Construction, foot, and vehicular traffic, recreational activities, and limited mulching may contribute to soil compaction in urban areas (Smiley et al. 1990). Alberty et al. (1984) assessed a variety of urban and suburban sites and found bulk densities ranging from 1.40 to $1.65 \mathrm{~g} \cdot \mathrm{cm}^{-3}$. These compaction levels were shown to limit biomass growth for various species; however, plant responses varied by species, intensity of compaction, soil water content, and soil textural types (Alberty et al. 1984; Pan and Bassuk 1985; Day and Bassuk 1994; Day et al. 2000). Low water and oxygen diffusion rates, reduction in saturated hydraulic conductivity, and reduction in infiltration and percolation rate of water characterize highly compacted soils (Boone and Veen 1994). Trees respond to compacted sites by producing shorter, thicker root systems, with more lateral branching (Taylor 1974; Pan and Bassuk 1985; Gilman et al. 1987; Liu and Waldron 1988), which can mean an increase in surface area of root systems per volume at shallow soil depths (Liu and Waldron 1988). Such altered root growth can make plants less drought tolerant and more susceptible to stress overall (Gilman et al. 1987; Watson et al. 1996). Additionally, compacted conditions can limit nutrient uptake for either the entire root system or only a portion (Lipiec and Stepniewski 1995). If the entire root system is not affected, the plant can still obtain sufficient levels of nutrients, and a deficiency will not be evident. Typically, the root:shoot ratio increases with compaction because height, caliper, and dry weights of plants are reduced with an increase in soil strength or density (Alberty et al. 1984; Masle and Passioura 1987; Cook et al. 1996; Montagu et al. 2001). Other studies found that although there were reductions in root dry weight due to compaction, the reductions were not significant (Andrade et al. 1993). Most often there is a pronounced response in aboveground biomass production (Taylor 1974; Pan and Bassuk 1985; Pittenger and Stamen 1990; Unger and Kaspar 1994; Day et al. 2000). Many of these physiological responses are similar to those brought on by water stress (Andrade et al. 1993; Whalley et al. 1995; Liang et al. 1999). Some tree species will adapt to compacted or dry soil conditions by developing an adventitious root system in the upper layers of the soil or in the mulch where impedance is reduced, aeration is greater, and water availability is higher (Hook and Brown 1973; Gilman et al. 1987; Liang et al. 1999). Although some species may adapt in this way, other species exposed to such stressors may not be able to recover when conditions abate over time, or recovery may be delayed for many days (Bengough and Young 1993), which can lead to increased plant stress. If responses to compaction and water stress are similar, one possible management strategy for compacted soils, in addition to loosening soil, is proper irrigation, especially during establishment.

Characterizing urban soils and tree response is difficult due to a wide variety of soil types, site conditions, and tree species planted. The challenge for urban forest managers is to find species that will grow and thrive in these variable urban sites. Anecdotally, many urban foresters believed high rates of nitrogen and irrigation during production reduced the establishment success of trees when planted in difficult urban sites. Some experts 
in the field (Sydnor, pers. comm., October 17, 2002, Columbus, Ohio, U.S.) supported this perception, indicating that trees "dependent" on fertilizer could not survive under fertility-challenged conditions. Others found that applying high levels of nitrogen fertilizer and adequate irrigation during production improved tree growth and establishment success (Lloyd et al. 2006). In practice, nurseries irrigate, fertilize, and root-prune both containerized and balled-and-burlapped trees to produce high quality, stress-resistant trees (Alan Erwin, Panther Creek Nursery, Willow Springs, North Carolina, U.S.; Mark Gantt, Hefner's Nursery, Conover, North Carolina, U.S.; Danny Vandevender, Landscape Design of Goldsboro, Pikeville, North Carolina, U.S., pers. comm., January 11, 2011, Greensboro, North Carolina, U.S.).

The primary objectives of this study were to assess the detrimental effects of soil compaction on growth of various cultivars of maple and to determine if pre-planting nitrogen rates affected establishment or growth of trees out-planted into compacted soils. Cultivars of Acer rubrum L. (red maple) and Acer $\times$ freemanii E. Murr. (Freeman maple), a naturally occurring hybrid of A. rubrum and A. saccharinum L. (silver maple), were selected because they represent a valuable group of plants used extensively as landscape and street trees (Sydnor and Cowan 2000). The study authors hypothesized that reduced hydraulic conductivity and reduced porosity characteristics of highdensity soils would reduce aboveground tree biomass, that the Freeman maple cultivars would be less negatively affected by compaction, and that a higher rate of $\mathrm{N}$ fertility during production would benefit tree performance in the compacted soils.

\section{MATERIALS AND METHODS}

\section{Tree Preparation}

Acer $\times$ freemanii 'Celzam' (Celebration ${ }^{\circledR}$ Freeman maple), Acer $\times$ freemanii 'Morgan' ('Morgan' Freeman maple), Acer $\times$ freemanii 'October Brilliance' ('October Brilliance' Freeman maple), Acer rubrum 'Bowhall' ('Bowhall' red maple), Acer rubrum 'Fairview Flame' (Fairview Flame ${ }^{\mathrm{TM}}$ red maple), Acer rubrum 'Frank's Red' (Red Sunset ${ }^{\circledR}$ red maple), Acer rubrum 'Magnificent Magenta' (Burgundy Belle ${ }^{\circledR}$ red maple), and Acer rubrum 'October Glory' (October Glory ${ }^{\circledast}$ red maple) were obtained from A. McGill \& Son Wholesale Nursery (Canby, Oregon, U.S.), John Holmlund Nursery, LLC. (Boring, Oregon, U.S.), and J. Frank Schmidt \& Son Co. (Boring, Oregon, U.S.). Trees were propagated from rooted cuttings and ranged from 25 to $31 \mathrm{~cm}$ in height. On April 15, 2001, trees were potted into $13 \mathrm{~L}$ black plastic, Root Right ${ }^{\mathrm{TM}}$ pots [Migratrol $^{\mathrm{TM}}$ (active ingredient: cuprous chloride, $5.6 \% \mathrm{w} / \mathrm{w}$ ), Chambersburg, Pennsylvania, U.S.]. The potting mix was a purchased blend $\left(15 \%\right.$ TechnaGro $^{\mathrm{TM}}, 60 \%$ pine bark, 20\% rice hulls, and $5 \%$ all others (Kurtz Bros., Inc. Groveport, Ohio, U.S.). Techna$\mathrm{Gro}^{\mathrm{TM}}$ is a soil conditioner made of hardwood bark, sawdust, and sewage sludge. Average nutrient contents were as follows: $2.4 \%$ total organic nitrogen, $1.3 \%$ phosphorous, and $0.2 \%$ potassium (Kurtz Bros. 1998). Pre-planting nitrogen $(\mathrm{N})$ treatments began on July 12, 2001, and continued for 13 weeks. Half the trees of each cultivar were randomly assigned to one of two N rates: 25 $\mathrm{mg}$ or $100 \mathrm{mg} \cdot \mathrm{L}^{-1} \mathrm{~N}$ fertigation from $20 \mathrm{~N}-4.3 \mathrm{P}-16.7 \mathrm{~K}$ Peters Water Soluble Fertilizer [ $20 \mathrm{~N}-10 \mathrm{P}_{2} \mathrm{O}_{5}-20 \mathrm{~K}_{2} 0$ with $8 \%$ ammonical N and $12 \%$ nitrate N, (O.M. Scotts Co., Marysville, Ohio, U.S.)] applied at $0.50 \mathrm{~L}$ in each of two daily irrigation cycles $\left(1 \mathrm{~L} \mathrm{~d}^{-1}\right.$ total). Rates and times were based on methodology from Struve (1995). Additionally, the $100 \mathrm{mg} \cdot \mathrm{L}^{-1} \mathrm{~N}$ rate represents the nursery standard application rate for production. Fertilizer was discontinued at the end of September 2001, prior to field planting.

\section{Compaction Procedure and Tree Installation}

The study was located at the Waterman Research and Education Facility in Columbus, Ohio, U.S. (Latitude $40.01^{\circ}$ and Longitude $-83.04^{\circ}$ ). The USDA Soil Conservation Service classified the soil at the facility as a Crosby silt loam, fine, mixed, mesic, aeric Ochraqualf type (McLoda and Parkinson 1980). In an undisturbed Crosby silt loam, the surface soil (down to $\sim 23 \mathrm{~cm}$ ) is characterized as a silt loam. Below this depth, it would typically be a clay loam or silty-clay loam (McLoda and Parkinson 1980).

In October 2001, soil compaction treatments were randomly assigned at the Waterman facility. All soil treatment plots were $17.7 \times 10.4 \mathrm{~m}$ and were arranged in the field in three replicates, from east to west with the three soil treatments laid out as whole plots, and split into sub-plots for low and standard nitrogen treatments, and split again into sub sub-plots for cultivar (cultivars were randomly located throughout nitrogen treatment sub-plots) (Figure 1).

For the six areas to be compacted, a loader bucket scraped off the vegetative layer, then removed soil from each to a depth of approximately $1 \mathrm{~m}$, keeping soil separate. A dump truck (4900-Series International, Warrenville, Illinois, U.S.) filled with building rubble and weighing approximately 14 tons was used to compact the base of each area by driving back and forth over each area six times. Three soil lifts of approximately 0.3 $\mathrm{m}$ depth were sequentially returned to each area and compacted individually using the same technique as with the base layer. Soil gravimetric water content $(\theta \mathrm{w})$ at the time of compaction was calculated as the mass of water in the soil per mass of oven-dried soil $\left(\mathrm{g} \cdot \mathrm{g}^{-1}\right)$, and ranged from 0.10 to $0.15 \mathrm{~g} \cdot \mathrm{g}^{-1}$ for the compacted plots. At the completion of the compaction treatment, the mean bulk dry density $\left(\rho_{\mathrm{b}}\right)$ for these plots was approximately $1.5 \mathrm{~g} \cdot \mathrm{cm}^{-3}$. Plots compacted in 2001 will be referred to as $\mathrm{C} 1$.

Prior to implementing compaction treatments, nine soil samples (approximately $0.91 \mathrm{~kg}$ each) were collected from the top $15 \mathrm{~cm}$ of the soil from across the entire study area and were air-dried at ambient room temperature for two months. These samples were used to perform a standard Proctor test, which determines a soil's maximum, practically achievable bulk density, following the methodology of the Iowa Department of Transportation (2004). Soil was pulverized and then passed through a $2 \mathrm{~mm}$ round-hole sieve. A cylindrical brass mold, $10.2 \mathrm{~cm}$ diameter by $11.6 \mathrm{~cm}$ height, was used to perform the Proctor test. A weighted, standardized tamper was used to compact the soil within the mold. Approximately $150 \mathrm{~g}$ of water was added to $3000 \mathrm{~g}$ of pulverized soil. Approximately one-third of this soil was added to the cylinder. The tamper was placed in the cylinder, the weight lifted and allowed to free-fall 25 times over the entire surface of the soil. The filled cylinder was weighed, then approximately $30 \mathrm{~g}$ of soil from the cylinder was placed in a tin, weighed, and set aside. This process was repeated until the weight of the compacted soil in the cylinder was less than in the previous runs (the point at which no more water could be added). Sample tins were placed in an oven at $105^{\circ} \mathrm{C}$ for approximately 24 hours to determine gravimetric water content, and these values were used to calculate volumetric water content, and wet and dry 


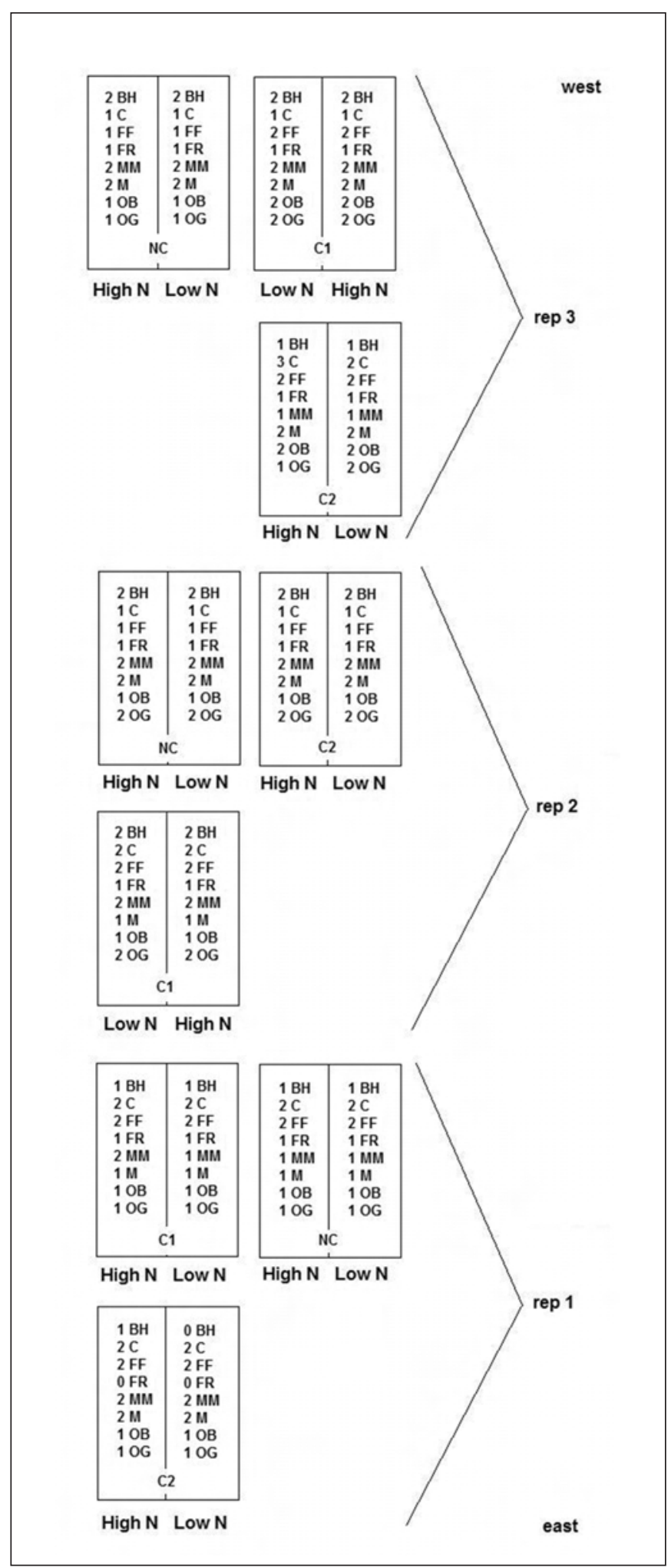

Figure 1. Layout of soil treatment whole plots, $\mathrm{N}$ treatment subplots, and the sub sub-plots showing the numbers of each cultivar (which were randomly located within the $\mathrm{N}$ treatment subplots) at Waterman Research and Education Facility in Columbus, Ohio, U.S. (not shown to scale). Mean bulk density for NC $=1.40$ $\mathrm{g} \cdot \mathrm{cm}^{-3}$, mean bulk density for $\mathrm{C} 1=1.60 \mathrm{~g} \cdot \mathrm{cm}^{-3}$, and mean bulk density for $\mathrm{C} 2=1.55 \mathrm{~g} \cdot \mathrm{cm}^{-3}$. densities. Bulk densities were plotted against percent volumetric water content to develop a Proctor density curve (not shown). The maximum practically-achievable bulk density, based on the physical and textural properties of the soil was $1.7 \mathrm{~g} \cdot \mathrm{cm}^{-3}$ at a volumetric water content of $0.31 \mathrm{~cm} \cdot \mathrm{cm}^{-3}$. Results from this test allowed us to assess the effectiveness of compaction efforts.

The Bouyoucos hydrometer method was used to analyze the field-soil texture, following methodology from Gee and Bauder (1986). Soil samples were taken, air-dried, and processed as for the Proctor test. In the eastern and central replicates the soil was classified as a silty-clay (19\% sand, $41 \%$ silt, and $40 \%$ clay) and in the western replicate a clay loam ( $23 \%$ sand, $39 \%$ silt, and $38 \%$ clay).

Three weeks prior to planting, Roundup ${ }^{\circledR}$ (glyphosate, $41 \%$ a.i., Monsanto, St. Louis, Missouri, U.S.) was applied to the non-compacted (NC) plots at the recommended rate of $15.7 \mathrm{ml}$ concentrate $\mathrm{L}^{-1}$ spray solution. Herbicide was applied to the NC plots initially to limit any potential increase in density that would result from the mechanical removal of vegetation as that used for the compacted plots. There is conflicting research regarding the effects of glyphosate on soil microorganisms. In their 2009 study, Zablotowicz et al. found that under no-till management (similar to the handling of the NC plots in this study), the use of glyphosate would have a minimal impact on soil microbial populations. Additionally, Busse et al. (2001) found that using glyphosate at field rates had little or no effect on the soil microbial community in ponderosa pine plantations. One study showed a $50 \%$ decrease in linear growth of 20 species of fungal colonies after 30 days, when soil in a boreal forest was treated with $50 \mathrm{mg} \cdot \mathrm{L}^{-1}$ glyphosate (Tanney and Hutchison 2010). Glyphosate use was continued throughout the study to control weeds in all whole treatment plots as needed. Wood chip mulch was placed on all treatment plots; therefore, its effects would have been similar across the entire study area.

On October 22, 2001, $30 \mathrm{~cm}$ diameter holes were augured and the sides of the holes were scored with a shovel. Trees were planted between October 23 and October 25, 2001, 3 m on center and cultivars were randomly assigned within the sub-plots (pre-plant $\mathrm{N}$ ). The roots were feathered-out, and trees were planted at grade depth. All cultivars were represented with at least two trees in each whole plot (soil treatments) with the exception of 'Frank's Red,' which was absent from plot C2, rep 1 (Figure 1). Additionally, each sub-plot (pre-plant N) had at least one tree of each cultivar, with the exception of plot $\mathrm{C} 2$ rep 1 , in which 'Frank's Red' was absent (as previously reported). Due to original availability of cuttings and mortality after field planting, there were an unequal number of trees of each cultivar (Figure 1). After planting, all treatment areas were mulched with un-composted wood chips to a depth of approximately $8 \mathrm{~cm}$.

Based on the results of the Proctor test, the study authors believed they could increase the $\rho_{\mathrm{b}}$ further, and therefore in July 2002 , half of the previously compacted plots were randomly selected and an additional soil treatment applied. The wood chip mulch was raked from the areas by hand. Plots were irrigated for 24 hours prior to applying the treatment. Soil samples were taken just prior to compaction and gravimetric water content measured as previously. From those values, mean $\theta \mathrm{w}$ was calculated as 0.14 $\mathrm{g} \cdot \mathrm{g}^{-1}$. A Bomag Model BW213PDH-3 vibrating, single drum, padfoot roller (Hellerwald, Germany) was driven between the rows of trees to compact the soil. Plots compacted in 2002 will be referred to as $\mathrm{C} 2$; these plots had a mean $\rho_{\mathrm{b}}$ of approximately $1.6 \mathrm{~g} \cdot \mathrm{cm}^{-3}$. 


\section{Soil Measurements}

Mulch and other organic matter were scraped from the surface, and nine intact cores $(7.6 \mathrm{~cm}$ length $\times 3.8 \mathrm{~cm}$ radius) were taken from random locations within each whole plot (soil treatment) each year of the study, using a slide hammer according to methodology described by Campbell and Henshall (1991). Soil was sampled outside of the root zone of the trees, from the top $6 \mathrm{~cm}$, which is where the majority of the absorbing roots are found (Perry 1982). Researchers weighed cores to obtain wet bulk density, and preserved the intact cores for hydraulic conductivity testing. Extra soil, obtained at sampling, was used to measure the gravimetric water content (as described earlier) and to calculate $\rho_{b}$ of each core (Blake and Hartge 1986). These values were verified after all testing was complete by oven drying and then weighing the dried cores to calculate $\rho_{b}$. From $\rho_{b}$ and known water content, air-filled porosity (AP) was determined. Water content at the permanent wilting point and available volumetric water content (AVWC) were determined using a tension table and pressure plate extractors (Soil Moisture Corp. Santa Barbara, California, U.S.), ranging from $0.5 \mathrm{MPa}$ to $1.5 \mathrm{MPa}$ suction, following methodology of Klute (1986), for the 2002 and 2003 cores. These values were used for development of a water-retention assessment (data not shown). AVWC was calculated by subtracting the volumetric water content values at field capacity $(-0.03 \mathrm{MPa})$ from those determined at permanent wilting point (-1.5 MPa). Due to laboratory time restrictions, these measurements were not taken in 2004. Saturated hydraulic conductivity $\left(\mathrm{K}_{\mathrm{s}}\right.$ ) was measured for the intact cores in the laboratory following Klute and Dirksen (1986).

\section{Tree Measurements}

The study authors measured trees at the beginning and end of each growing season from 2002 through 2004. Caliper was measured at $15.2 \mathrm{~cm}$ above the ground at the beginning and end of each growing season. Two measurements of diameter were taken at a 90 degree angle from each other at the same height on the trunk, and averaged to determine caliper. Caliper growth was calculated based on beginning and end of season caliper measurements. In addition, caliper growth was calculated for the entire study period based on caliper at the beginning of the 2002 growing season and the end of the study in 2004. Cross-sectional area was determined as the area of a circle. As maples often have more than one dominant leader, total height was determined by averaging the measured height (from ground level) of the three dominant leaders on each tree. Height growth was calculated from beginning and endof-season height measurements for each year. Three trees were randomly selected from each sub sub-plot (cultivar), from each whole plot (soil) and sub-plot ( $\mathrm{N}$ treatment) to assess leaf area (LA) and leaf dry weight (LDW). In 2004, only four cultivars were sampled to accommodate limited field time in the final year of the study. The following cultivars were selected because they were more commonly used in urban landscapes in Ohio: 'Celzam,' 'Morgan,' 'Fairview Flame,' and 'Frank's Red.' All foliage was harvested from each tree prior to leaf drop each year. In 2002, all the leaves were used to determine LA, using a Li-Cor 3100 Area Meter (Li-Cor, Inc., Lincoln, Nebraska, U.S.). Leaves were oven-dried at $82^{\circ} \mathrm{C}$ for two to three days, and then weighed to determine LDW. In 2003 and 2004, random samples totaling 100 and 500 leaves, respectively, were used from the entire canopy of each tree harvested. The area of the samples was measured us- ing the Li-Cor meter and dried/weighed as before. The remaining portion of the leaf canopy was dried/weighed separately. An estimated LA for the entire tree canopy was calculated by multiplying the area of the sample by the dry weight of the remaining portion of the canopy and dividing this value by the dry weight of the sample. In 2004, the same trees used for leaf measures were also used to determine stem dry weight (SDW). Stems were harvested at ground level, air-dried in an unventilated, dry polyhouse for one month, and then weighed. Air-drying was done due to limited space in the drying ovens and the large volume of stem materials.

In 2004, upon completion of the study, a small sample $(\mathrm{n}=$ 7, $2 \mathrm{C} 1,3 \mathrm{NC}$, and $2 \mathrm{C} 2$ trees) of tree roots were completely excavated using an air trenching tool (Air-Spade ${ }^{\circledR}$, Chicopee, Massachusetts, U.S.). Although provided with an insufficient number for statistical analysis, the study authors documented these root systems with photos and will discuss them anecdotally.

\section{Experimental design and data analysis}

A split-split plot design was used. The three soil treatments were randomized into whole plots in each of three replicates. Each whole plot was split into two sub-plots with trees treated with low or high $\mathrm{N}$ grouped separately. Cultivars were randomized throughout each fertilizer sub-plot into sub sub-plots. Data were analyzed using SAS's general linear model procedure (PROC GLM) to determine significant differences between soil, fertilizer and cultivar treatments and interactions between each of these and all three (SAS Institute, Inc., Cary, North Carolina, U.S.). Comparisons were made between these treatments using Tukey's honestly significant difference (HSD). Treatment differences were considered significant if $P$ values were equal to or less than 0.05 . The AP and $\mathrm{K}_{\mathrm{s}}$ measurements were found to be well described by a log-normal distribution. The logarithmic-transformed AP and $\mathrm{K}_{\mathrm{s}}$ values were then analyzed using GLM and Tukey's procedures. Mean values for soil parameters and aboveground growth were analyzed both within each year and from year to year.

\section{RESULTS}

\section{The Effect of Compaction Treatments on Soil Physical Characteristics}

The mean $\rho_{\mathrm{b}}$ over the three-year study was $1.42 \mathrm{~g} \cdot \mathrm{cm}^{-3}$ for the NC soils and $1.59 \mathrm{~g} \cdot \mathrm{cm}^{-3}$ for the two compaction treatments (Table 1). This reflects a $12 \%$ increase over the mean pre-existing $\rho_{\mathrm{b}}$. The $\mathrm{C} 2$ treatment did not significantly increase bulk density over $\mathrm{C} 1$. Values for soil measurements did not change significantly from year to year (data not shown).

In all years of the study, percent AP was significantly lower in the compacted soils than in the NC soils with the exception of 2004, when there was only a difference between NC and $\mathrm{C} 1$ soils. On average, NC soils had an AP of $11 \%$, while the $\mathrm{C} 1$ and $\mathrm{C} 2$ soils had values of $5 \%$ and $4 \%$, respectively.

In all study years, NC plots had significantly higher mean $\mathrm{K}_{\mathrm{s}}$ than soils in either compaction treatment, although these did not significantly differ from one another (Table 1 ). $\mathrm{K}_{\mathrm{s}}$ values were highly variable across all samples likely due to the exceedingly heterogeneous nature of field soils. This is common with such measurements (Coutadeur et al. 2002). Despite the variability, all $\mathrm{NC}$ sample $\mathrm{K}_{\mathrm{s}}$ and $\log \left(\mathrm{K}_{\mathrm{s}}\right)$ values were above 
zero, which also indicates a higher flow rate in the lower density soils (Table 1). Water content at the permanent wilting point was lower in the NC soils than in the compacted soils, and NC soils had more AVWC than the compacted soils (Table 1).

\section{Tree Growth}

For each year of the study, height varied based on cultivar type, but did not differ due to any other experimental treatment (data not shown). The rate of annual height growth also differed between cultivars in 2003 and 2004 (Table 2 ), but was unaffected by other experimental treatments.

Caliper growth rate $\left(\mathrm{cm} \cdot \mathrm{yr}^{-1}\right)$ across all cultivars varied significantly due to soil treatment in 2002 (Table 3; Table 4; Fig- ure 2) and 2003 (Table 3; Table 4). In 2002, trees growing in $\mathrm{NC}$ plots increased caliper on average $83 \%$ more than did trees growing in the compacted plots (Figure 2). 'Celzam' Freeman maple put on significantly more caliper growth than all other cultivars despite compaction treatment (Table 3; Table 4; Figure 2). When compared to 'Morgan' Freeman maples (poorest performer in 2002), 'Celzam' averaged $118 \%$ more annual caliper growth in NC plots, and in compacted plots 'Fairview Flame' put on 142\% more caliper growth than 'Morgan.' In 2003, trees growing in $\mathrm{NC}$ plots put on $22 \%$ more caliper growth than trees in compacted plots, and cultivars differed significantly (Table 3; Table 4). In 2004, cultivars differed in annual caliper growth, but not in response to compaction or pre-plant $\mathrm{N}$ rates (Table 2). When comparing annual caliper growth in 2002 and 2004,

Table 1. Mean dry bulk density ( $\rho b)$, log-transformed air-filled pore space (Log(AP)), log-transformed saturated hydraulic conductivity (Log(Ks)), water content at permanent wilting point (PWP), and available volumetric water content (AVWC) for each soil treatment for each study year. Values were obtained by measuring 9 intact soil cores taken each year from each whole plot (soil treatment).

\begin{tabular}{|c|c|c|c|c|c|c|}
\hline Year & $\begin{array}{l}\text { Soil } \\
\text { treatment }^{2}\end{array}$ & $\rho b\left(\mathrm{~g} \cdot \mathrm{cm}^{-3}\right)$ & $\begin{array}{l}\log (\mathrm{AP}) \\
\left(\mathrm{cm}^{3} \cdot \mathrm{cm}^{-3}\right)\end{array}$ & $\begin{array}{l}\log (\mathrm{Ks}) \\
\left(\mathrm{cm} \cdot \mathrm{hr}^{-1}\right)\end{array}$ & $\begin{array}{l}\text { PWP } \\
\left(\mathrm{cm}^{3} \cdot \mathrm{cm}^{-3}\right)\end{array}$ & $\begin{array}{l}\text { AVWC } \\
\left(\mathrm{cm}^{3} \cdot \mathrm{cm}^{-3}\right)\end{array}$ \\
\hline \multirow[t]{2}{*}{2002} & $\mathrm{NC}$ & $1.43 \pm 0.04 \mathrm{a}$ & $-1.11 \pm 0.15 \mathrm{a}$ & $1.1 \pm 0.2 \mathrm{a}$ & $0.20 \pm 0.02 \mathrm{a}$ & $0.18 \pm 0.02 \mathrm{a}$ \\
\hline & $\mathrm{C} 1$ & $1.67 \pm 0.05 b$ & $-1.66 \pm 0.16 b$ & $0.01 \pm 0.1 b$ & $0.26 \pm 0.02 b$ & $0.10 \pm 0.01 b$ \\
\hline \multirow[t]{3}{*}{2003} & $\mathrm{NC}$ & $1.43 \pm 0.05 \mathrm{a}$ & $-0.99 \pm 0.12 \mathrm{a}$ & $1.2 \pm 0.3 \mathrm{a}$ & $0.20 \pm 0.01 \mathrm{a}$ & $0.21 \pm 0.02 \mathrm{a}$ \\
\hline & $\mathrm{C} 1$ & $1.58 \pm 0.04 b$ & $-1.31 \pm 0.13 b$ & $0.6 \pm 0.2 b$ & $0.24 \pm 0.01 b$ & $0.13 \pm 0.01 b$ \\
\hline & $\mathrm{C} 2$ & $1.58 \pm 0.02 b$ & $-1.39 \pm 0.18 b$ & $0.2 \pm 0.2 b$ & $0.22 \pm 0.003 \mathrm{c}$ & $0.16 \pm 0.01 b$ \\
\hline \multirow[t]{2}{*}{2004} & $\mathrm{NC}$ & $1.42 \pm 0.06 \mathrm{a}$ & $-1.37 \pm 0.14 \mathrm{a}$ & $2.2 \pm 0.3 \mathrm{a}$ & $\mathrm{nm}$ & $\mathrm{nm}$ \\
\hline & $\mathrm{C} 2$ & $1.49 \pm 0.06 \mathrm{ab}$ & $-1.55 \pm 0.12 \mathrm{ab}$ & $0.5 \pm 0.2 \mathrm{~b}$ & $\mathrm{~nm}$ & $\mathrm{~nm}$ \\
\hline
\end{tabular}

${ }^{\mathrm{z}} \mathrm{NC}=$ non-compacted treatment, $\mathrm{C} 1=$ compacted once, $\mathrm{C} 2=$ compacted twice; $\mathrm{n}=$ nine samples for each soil treatment per year. Means \pm standard errors followed by different letters indicate a significant difference between treatment measurements within each year, at $P \leq 0.05$ (Tukey's honestly significant difference test, HSD); "nm" means not measured in that year.

Table 2. Analysis of variance effects significance for mean height growth, mean caliper growth, mean leaf area, mean leaf dry weight, and mean stem dry weight for each soil treatment, with eight maple cultivars, three soil treatments, two pre-planting nitrogen $(\mathrm{N})$ rates, the interactions between soil treatment, cultivar, and pre-planting $\mathrm{N}$ rate for all study years.

\begin{tabular}{|c|c|c|c|c|c|}
\hline $\begin{array}{l}\text { Analysis of } \\
\text { variance effects }\end{array}$ & $\begin{array}{l}\text { Height growth } \\
(\mathrm{cm})\end{array}$ & $\begin{array}{l}\text { Caliper growth } \\
(\mathrm{cm})\end{array}$ & $\begin{array}{l}\text { Leaf area } \\
\left(\mathrm{m}^{2}\right)\end{array}$ & $\begin{array}{l}\text { Leaf dry } \\
\text { weight }(\mathrm{g})\end{array}$ & $\begin{array}{l}\text { Stem dry } \\
\text { weight }(\mathrm{g})\end{array}$ \\
\hline \multicolumn{6}{|l|}{2002} \\
\hline Cultivar (C) & $\mathrm{ns}^{\mathrm{z}}$ & $* * *$ & $* * *$ & $* * *$ & $\mathrm{~nm}$ \\
\hline Soil treatment & ns & $*$ & ns & ns & $\mathrm{nm}$ \\
\hline $\mathrm{N}$ rate $(\mathrm{N})$ & ns & ns & $*$ & $*$ & $\mathrm{~nm}$ \\
\hline Soil treatment*cultivar & ns & $*$ & ns & ns & $\mathrm{nm}$ \\
\hline Cultivar* $\mathrm{N}$ rate & ns & $\mathrm{ns}$ & $* *$ & ns & $\mathrm{nm}$ \\
\hline Soil treatment ${ }^{*} \mathrm{~N}$ rate & ns & ns & ns & ns & $\mathrm{nm}$ \\
\hline Soil treatment ${ }^{*} \mathrm{C} * \mathrm{~N}$ & ns & ns & ns & ns & $\mathrm{nm}$ \\
\hline \multicolumn{6}{|l|}{2003} \\
\hline Cultivar & $* * *$ & $* * *$ & $* * *$ & $* * *$ & $\mathrm{~nm}$ \\
\hline Soil treatment & ns & $* *$ & $* *$ & $* *$ & $\mathrm{~nm}$ \\
\hline $\mathrm{N}$ rate & ns & ns & $* *$ & $* *$ & $\mathrm{~nm}$ \\
\hline Soil treatment* ${ }^{*}$ cultivar & ns & ns & $* *$ & $* *$ & $\mathrm{~nm}$ \\
\hline Cultivar* $\mathrm{N}$ rate & ns & ns & ns & ns & $\mathrm{nm}$ \\
\hline Soil treatment* $\mathrm{N}$ rate & ns & ns & ns & ns & $\mathrm{nm}$ \\
\hline Soil treatment ${ }^{*} \mathrm{C}^{*} \mathrm{~N}$ & ns & ns & ns & ns & $\mathrm{nm}$ \\
\hline Cultivar & $* * *$ & $* * *$ & $* * *$ & $* * *$ & $* * *$ \\
\hline Soil treatment & ns & $\mathrm{ns}$ & $* *$ & $* *$ & $*$ \\
\hline $\mathrm{N}$ rate & ns & ns & $* *$ & $* *$ & $* * *$ \\
\hline Soil treatment*cultivar & ns & $\mathrm{ns}$ & ns & ns & $*$ \\
\hline Cultivar* $\mathrm{N}$ rate & ns & ns & ns & ns & $* *$ \\
\hline Soil treatment ${ }^{*} \mathrm{~N}$ rate & ns & ns & ns & $\mathrm{ns}$ & ns \\
\hline Soil treatment $* C * N$ & ns & ns & ns & ns & ns \\
\hline
\end{tabular}

${ }^{2}$ Asterisks (*,**,***) and "ns" indicate statistical significance of the treatment at $P \leq 0.05, P \leq 0.01, P \leq 0.001$, or not significant, respectively; "nm" means not measured in that year. All possible interactions for the main experimental treatments (soil treatment whole plots, pre-plant nitrogen rate sub-plots, and cultivar sub sub-plots) were tested. 
cultivars responded differently to compaction (Table 3; Table 4; Figure 2). As indicated in 2002, there was an $83 \%$ difference in caliper growth as bulk density increased. In 2004, however, this disparity had decreased to $6 \%$ (Table 3; Table 4; Figure 2). It seems that after an initial setback in 2002 and 2003, trees growing in the compacted soils began to put on caliper almost as fast as those trees growing in the NC soils in 2004. In 2004, there was no difference in caliper growth rate between soil treatments (Table 2), further supporting this observation.

LA and LDW responses varied among the cultivars throughout the study (Table 2; Table 7). In 2002, there was no soil treatment effect (Table 2). In 2003 and 2004, most cultivars had significantly smaller LA and LDW values (data not shown) when grown in the compacted plots compared to those growing in the NC plots. The exceptions were 'Bowhall' and 'Magnificent Magenta' red maples, which were unaffected by high-density soils in 2003, and were not measured in 2004.

Stems that were destructively harvested in 2004 showed a variable response to compaction based on cultivar (Table 2). Despite the soil treatment, 'Celzam' and 'Morgan' Freeman maples had significantly larger SDW values than both red maples 'Fairview Flame' and 'Frank's Red' (Table 5). Most trees growing in the NC plots had larger SDW than the trees growing in compacted soils (Table 5).

Trees receiving $100 \mathrm{mg} \cdot \mathrm{L}^{-1} \mathrm{~N}$ had significantly larger LA and LDW in 2003 and 2004 (Table 2) when compared to trees receiving the low rate, $25 \mathrm{mg} \cdot \mathrm{L}^{-1} \mathrm{~N}$. There was an interaction between $\mathrm{N}$ rate and cultivar for LA values in 2002 (Table 2; Table 6). SDW response to $\mathrm{N}$ rate varied across cultivars, most responding positively to the higher rate, the exception being 'Frank's Red' (Table 5). The SDW of 'Frank's Red' trees was larger at $25 \mathrm{mg} \cdot \mathrm{L}^{-1} \mathrm{~N}$ than the standard rate. This is surprising and requires further investigation, but may be an anomaly of the small sample size. Additionally, at the standard $\mathrm{N}$ rate, Freeman maple cultivars had a larger mean SDW than the red maples, but there was no clear-cut difference at the low rate (Table 5). Pre-plant N rate had no effect on annual caliper growth (Table 2), and cultivar response was confounding (Table 6). No cultivar showed a well-defined relationship between $\mathrm{N}$ rate and caliper growth.

Table 3. Mean caliper growth per year for three Freeman maple cultivars for each soil treatment and in each year measured. For each cultivar and each soil treatment, the sample size is in parentheses.

\begin{tabular}{llll}
\hline Cultivar & Soil treatments & Caliper Growth $\left(\mathrm{cm} \cdot \mathrm{yr}^{-1}\right)$ & \\
& & Year & 2003 \\
\hline 'Celzam' & $\mathrm{NC}(\mathrm{n}=8)$ & $0.78 \pm 0.20 \mathrm{a}$ & $2.5 \pm 0.1 \mathrm{a}$ \\
& $\mathrm{C} 1(\mathrm{n}=10)$ & $0.20 \pm 0.03 \mathrm{~b}$ & $1.8 \pm 0.1 \mathrm{~b}$ \\
& $\mathrm{C} 2(\mathrm{n}=11)$ & $0.12 \pm 0.04 \mathrm{~b}$ & $1.4 \pm 0.1 \mathrm{~b}$ \\
\hline 'Morgan' & $\mathrm{NC}(\mathrm{n}=10)$ & $0.20 \pm 0.07 \mathrm{a}$ & $1.5 \pm 0.1 \mathrm{a}$ \\
& $\mathrm{C} 1(\mathrm{n}=8)$ & $0.08 \pm 0.02 \mathrm{a}$ & $1.0 \pm 0.1 \mathrm{~b}$ \\
& $\mathrm{C} 2(\mathrm{n}=12)$ & $0.01 \pm 0.01 \mathrm{a}$ & $0.9 \pm 0.1 \mathrm{~b}$ \\
\hline 'October Brilliance' & $\mathrm{NC}(\mathrm{n}=6)$ & $0.48 \pm 0.11 \mathrm{a}$ & $1.7 \pm 0.1 \mathrm{a}$ \\
& $\mathrm{C} 1(\mathrm{n}=8)$ & $0.20 \pm 0.03 \mathrm{~b}$ & $1.4 \pm 0.1 \mathrm{a}$ \\
& $\mathrm{C} 2(\mathrm{n}=8)$ & $0.18 \pm 0.02 \mathrm{~b}$ & $1.1 \pm 0.1 \mathrm{a}$ \\
\hline
\end{tabular}

${ }^{\mathrm{z}} \mathrm{NC}=$ non-compacted, $\mathrm{C} 1$ = compacted once, $\mathrm{C} 2=$ twice-compacted. Means \pm standard error followed by different letters indicate a significant difference between soil treatments within cultivar Acer $\times$ freemanii 'Celzam' (Celebration Freeman maple; $\mathrm{n}=)$, Acer $\times$ freemanii 'Morgan' ('Morgan' Freeman maple), Acer $\times$ freemanii 'October Brilliance' ('October Brilliance' Freeman maple), at the $P \leq 0.05$ (Tukey's honestly significant difference test, HSD).

Table 4. Mean caliper growth per year for four red maple cultivars for each soil treatment and in each year measured. For each cultivar and each soil treatment, the sample size is in parentheses.

\begin{tabular}{|c|c|c|c|c|}
\hline Cultivar & Soil treatments ${ }^{2}$ & $\begin{array}{l}\text { Caliper growth }\left(\mathrm{cm} \cdot \mathrm{yr}^{-1}\right) \\
\text { Year } \\
2002\end{array}$ & 2003 & 2004 \\
\hline 'Bowhall' & $\begin{array}{l}\mathrm{NC}(\mathrm{n}=10) \\
\mathrm{C} 1(\mathrm{n}=10) \\
\mathrm{C} 2(\mathrm{n}=7)\end{array}$ & $\begin{array}{l}0.24 \pm 0.07 \mathrm{a} \\
0.11 \pm 0.03 \mathrm{a} \\
0.12 \pm 0.03 \mathrm{a}\end{array}$ & $\begin{array}{l}1.1 \pm 0.1 \mathrm{a} \\
1.1 \pm 0.1 \mathrm{a} \\
1.1 \pm 0.2 \mathrm{a} \\
\end{array}$ & $\begin{array}{l}1.0 \pm 0.1 \mathrm{a} \\
1.1 \pm 0.1 \mathrm{a} \\
1.0 \pm 0.1 \mathrm{a}\end{array}$ \\
\hline 'Fairview Flame' & $\begin{array}{l}\mathrm{NC}(\mathrm{n}=8) \\
\mathrm{C} 1(\mathrm{n}=10) \\
\mathrm{C} 2(\mathrm{n}=10)\end{array}$ & $\begin{array}{l}0.46 \pm 0.08 \mathrm{a} \\
0.38 \pm 0.05 \mathrm{a} \\
0.26 \pm 0.05 \mathrm{a} \\
\end{array}$ & $\begin{array}{l}1.9 \pm 0.1 \mathrm{a} \\
1.4 \pm 0.1 \mathrm{~b} \\
1.2 \pm 0.1 \mathrm{~b} \\
\end{array}$ & $\begin{array}{l}1.8 \pm 0.1 \mathrm{a} \\
1.7 \pm 0.1 \mathrm{a} \\
1.6 \pm 0.1 \underline{\mathrm{a}} \\
\end{array}$ \\
\hline 'Frank's Red' & $\begin{array}{l}\mathrm{NC}(\mathrm{n}=6) \\
\mathrm{C} 1(\mathrm{n}=6) \\
\mathrm{C} 2(\mathrm{n}=4)\end{array}$ & $\begin{array}{l}0.41 \pm 0.10 \mathrm{a} \\
0.20 \pm 0.04 \mathrm{a} \\
0.08 \pm 0.03 \mathrm{a} \\
\end{array}$ & $\begin{array}{l}1.8 \pm 0.1 \mathrm{a} \\
1.0 \pm 0.3 \mathrm{~b} \\
1.1 \pm 0.1 \mathrm{~b} \\
\end{array}$ & $\begin{array}{l}1.2 \pm 0.1 \mathrm{a} \\
1.7 \pm 0.3 \mathrm{a} \\
1.4 \pm 0.2 \mathrm{a}\end{array}$ \\
\hline 'Magnificent Magenta' & $\begin{array}{l}\mathrm{NC}(\mathrm{n}=10) \\
\mathrm{C} 1(\mathrm{n}=10) \\
\mathrm{C} 2(\mathrm{n}=10)\end{array}$ & $\begin{array}{l}0.23 \pm 0.08 \mathrm{a} \\
0.15 \pm 0.02 \mathrm{~b} \\
0.14 \pm 0.03 \mathrm{~b}\end{array}$ & $\begin{array}{l}1.6 \pm 0.1 \mathrm{a} \\
1.3 \pm 0.1 \mathrm{~b} \\
1.0 \pm 0.1 \mathrm{~b}\end{array}$ & $\begin{array}{l}1.9 \pm 0.1 \mathrm{a} \\
1.7 \pm 0.2 \mathrm{ab} \\
1.6 \pm 0.1 \mathrm{~b}\end{array}$ \\
\hline 'October Glory' & $\begin{array}{l}\mathrm{NC}(\mathrm{n}=8) \\
\mathrm{C} 1(\mathrm{n}=8) \\
\mathrm{C} 2(\mathrm{n}=7)\end{array}$ & $\begin{array}{l}0.52 \pm 0.06 \mathrm{a} \\
0.27 \pm 0.05 \mathrm{~b} \\
0.23 \pm 0.03 \mathrm{~b}\end{array}$ & $\begin{array}{l}1.8 \pm 0.1 \mathrm{a} \\
1.1 \pm 0.1 \mathrm{~b} \\
1.2 \pm 0.2 \mathrm{~b}\end{array}$ & $\begin{array}{l}1.6 \pm 0.1 \mathrm{a} \\
1.6 \pm 0.1 \mathrm{a} \\
1.7 \pm 0.1 \mathrm{a}\end{array}$ \\
\hline
\end{tabular}

${ }^{\mathrm{z}} \mathrm{NC}=$ non-compacted, $\mathrm{C} 1$ = compacted once, $\mathrm{C} 2=$ twice-compacted. Means \pm standard error followed by different letters indicate a significant difference between soil treatments, for each cultivar Acer rubrum 'Bowhall' ('Bowhall' red maple), Acer rubrum 'Fairview Flame' (Fairview Flame red maple), Acer rubrum, 'Frank's Red' (Red Sunset red maple), Acer rubrum 'Magnificent Magenta' (Burgundy Belle red maple), and Acer rubrum 'October Glory' (October Glory red maple), at the $P \leq 0.05$ (Tukey's honestly significant difference HSD). 


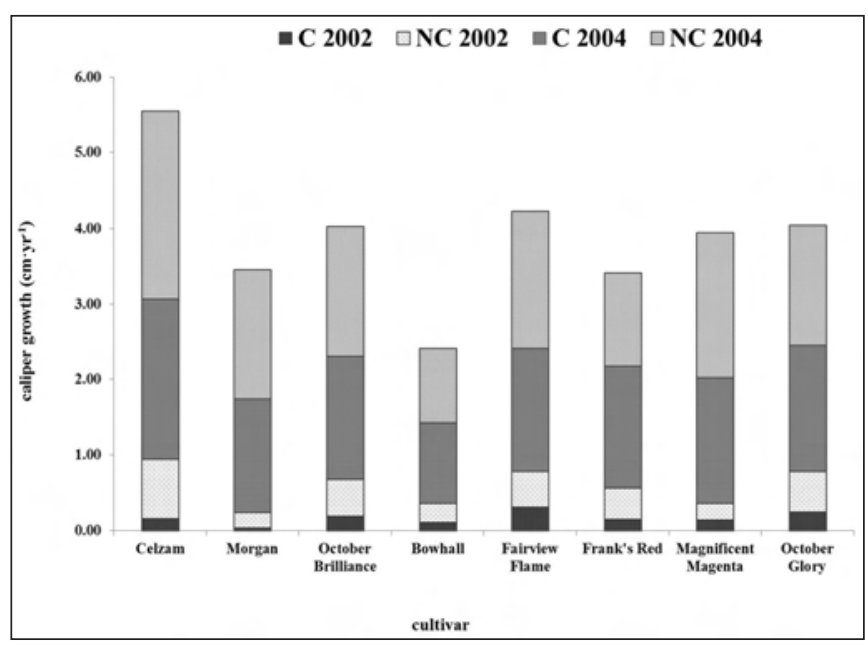

Figure 2. Mean annual caliper growth $\left(\mathrm{cm} \cdot \mathrm{yr}^{-1}\right)$ of eight cultivars of Freeman and red maple trees growing in non-compacted and compacted soil treatments measured in 2002 and 2004. NC = noncompacted, $\mathrm{C}=$ mean of plots compacted once and twice (C2); Acer $\times$ freemanii 'Celzam' (Celebration Freeman maple), Acer $\times$ freemanii 'Morgan' ('Morgan' $\times$ Freeman maple), Acer $\times$ freemanii 'October Brilliance' ('October Brilliance' Freeman maple), Acer rubrum 'Bowhall' ('Bowhall' red maple), Acer rubrum 'Fairview Flame' (Fairview Flame red maple), Acer rubrum, 'Frank's Red' (Red Sunset red maple), Acer rubrum 'Magnificent Magenta' (Burgundy Belle red maple), and Acer rubrum 'October Glory' (October Glory red maple).

Only the red maple cultivar 'Bowhall' was unaffected by soil or pre-plant $\mathrm{N}$ treatments. The 'Bowhall' trees were on average much smaller than all other cultivars over all the biomass measures (Table 3; Table 4). One possible explanation for this anomaly is that 'Bowhall' is not suited to clay-based soil types, regardless of whether they are compacted. 'Celzam,' a Freeman maple, on average had larger mean biomass measures when compared to all other cultivars, irrespective of soil treatment (Table 3; Table 4); although 'Celzam' trees grown in compacted plots had smaller mean biomass measures than trees growing in NC plots (Table 3). In addition, 'Celzam' had larger SDW values than both red maples despite the pre-plant $\mathrm{N}$ rate (Table 5).

\section{DISCUSSION}

\section{The Effect of Compaction Treatments on Soil Physical Characteristics.}

The additional compaction treatment in 2002 did not increase the $\rho_{\mathrm{b}}$ as hoped, and on average was actually lower than the $\rho_{\mathrm{b}}$ of soils compacted initially, however not significantly. This could be because rocks or other natural differences across the field may have led to less-than-homogenous compaction (Maurya and Lal 1979). Based on the Proctor results, the volumetric water content at the time of the second compaction treatment $(0.14$ $\mathrm{g} \cdot \mathrm{g}^{-1}$ ) was insufficient to raise the bulk density substantially. The Proctor test was done in a laboratory and determined the maximum, practically achievable soil density at the highest possible water content and done under non-compacted conditions. In the field, working under compacted conditions limited the amount of water the soil could absorb. Additionally, the pad-foot roller
Table 5. Mean stem dry weight for four cultivars of Freeman and red maple trees harvested in 2004; values shown for soil treatments and pre-plant nitrogen rates.

\begin{tabular}{|c|c|c|c|}
\hline \multirow[t]{3}{*}{ Cultivar $^{2}$} & \multicolumn{3}{|c|}{ Stem dry weight (g) } \\
\hline & \multicolumn{3}{|c|}{ Soil treatment ${ }^{y}$} \\
\hline & $\overline{\mathrm{NC}}$ & $\mathrm{C} 1$ & $\mathrm{C} 2$ \\
\hline 'Celzam' & 5625 a (a) & $3642 \mathrm{a}(\mathrm{ab})$ & 2407 a (b) \\
\hline 'Morgan' & 5150 a (a) & $2500 \mathrm{~b}(\mathrm{~b})$ & 2367 a (b) \\
\hline 'Fairview Flame' & 3068 b (a) & $1567 \mathrm{c}(\mathrm{b})$ & $2200 \mathrm{a}(\mathrm{ab})$ \\
\hline \multirow[t]{4}{*}{ 'Frank's Red' } & $2108 \mathrm{~b}(\mathrm{a})$ & 1400 c (b) & $1238 \mathrm{~b}(\mathrm{~b})$ \\
\hline & \multicolumn{3}{|c|}{ Stem dry weight (g) } \\
\hline & \multicolumn{3}{|c|}{ Pre-plant $\mathrm{N}$ rate ${ }^{\mathrm{x}}$} \\
\hline & $\mathrm{H}$ & $\mathrm{L}$ & \\
\hline 'Celzam' & 4972 a (a) & 2770 a (a) & \\
\hline 'Morgan' & 4228 a (a) & $2450 \mathrm{ab}(\mathrm{a})$ & \\
\hline 'Fairview Flame' & $2667 \mathrm{~b}(\mathrm{a})$ & 1920 bc (a) & \\
\hline 'Frank's Red' & $1580 \mathrm{~b}(\mathrm{~b})$ & $1750 \mathrm{c} \mathrm{(a)}$ & \\
\hline
\end{tabular}

${ }^{z}$ Acer $\times$ freemanii 'Celzam' (Celebration Freeman maple, [ $\left.\left.=19\right]\right)$, Acer $\times$ freemanii 'Morgan' ('Morgan' Freeman maple, $[\mathrm{n}=18]$ ), Acer rubrum 'Fairview Flame' (Fairview Flame red maple, $[\mathrm{n}=19])$, and Acer rubrum, 'Frank's Red' (Red Sunset red maple, $[\mathrm{n}=16]$ ), at the $P \leq 0.05$ (Tukey's honestly significant difference HSD).

${ }^{y}$ Means followed by different letters indicate a significant difference between cultivars within each soil treatment $(\mathrm{NC}=$ non-compacted, $\mathrm{C} 1=$ compacted once, $\mathrm{C} 2$ = twice-compacted)

${ }^{x}$ Means followed by different letters indicate a significant difference between cultivars within each pre-plant $\mathrm{N}$ treatments. Standard rate $\left[\mathrm{H}: 100 \mathrm{mg} \cdot \mathrm{L}^{-1}\right.$ or Low rate $\mathrm{L}: 25 \mathrm{mg} \cdot \mathrm{L}^{-1}$ ] . Means followed by different letters within parentheses indicate a significant difference between the soil treatments or the pre-plant $\mathrm{N}$ treatments for each cultivar.

Table 6. Mean leaf area values measured in the 2002 growing season for each cultivar (sample size in parentheses), showing responses to two different pre-planting nitrogen $(\mathrm{N})$ rates.

\begin{tabular}{lll}
\hline Cultivar & \multicolumn{2}{l}{ Leaf area $\left(\mathrm{m}^{2}\right)$} \\
\cline { 2 - 3 } & Pre-plant N rate \\
\cline { 2 - 3 } & $\mathrm{H}$ & $\mathrm{L}$ \\
\hline 'Celzam' ( $\mathrm{n}=17)$ & $2.1 \mathrm{a}$ & $1.8 \mathrm{a}$ \\
'Morgan' $(\mathrm{n}=18)$ & $1.3 \mathrm{c}$ & $1.0 \mathrm{~cd}$ \\
'October Brilliance' $(\mathrm{n}=10)$ & $0.9 \mathrm{~d}$ & $0.7 \mathrm{de}$ \\
'Bowhall' ( $\mathrm{n}=17)$ & $0.7 \mathrm{~d}$ & $0.5 \mathrm{e}$ \\
'Fairview Flame' $(\mathrm{n}=18)$ & $2.1 \mathrm{a}$ & $1.3 \mathrm{bc}$ \\
'Frank's Red' $(\mathrm{n}=16)$ & $1.4 \mathrm{bc}$ & $1.2 \mathrm{bc}$ \\
'Magnificent Magenta' $(\mathrm{n}=17)$ & $1.0 \mathrm{~cd}$ & $0.9 \mathrm{dc}$ \\
'October Glory' $(\mathrm{n}=17)$ & $1.7 \mathrm{ab}$ & $1.5 \mathrm{de}$ \\
\hline
\end{tabular}

${ }^{2}$ Acer $\times$ freemanii 'Celzam' (Celebration Freeman maple), Acer $\times$ freemanii 'Morgan' ('Morgan' Freeman maple), Acer $\times$ freemanii 'October Brilliance' ('October Brilliance' Freeman maple), Acer rubrum 'Bowhall' ('Bowhall' red maple), Acer rubrum 'Fairview Flame' (Fairview Flame red maple), Acer rubrum 'Frank's Red' (Red Sunset red maple), Acer rubrum 'Magnificent Magenta' (Burgundy Belle red maple), and Acer rubrum 'October Glory' (October Glory red maple).

${ }^{y}$ Means followed by different letters indicate a significant difference between cultivars within each pre-plant $\mathrm{N}$ treatment. Standard rate $\left[\mathrm{H}: 100 \mathrm{mg} \cdot \mathrm{L}^{-1}\right]$ or Low rate [L: $25 \mathrm{mg} \cdot \mathrm{L}^{-1}$ ], at the $P \leq 0.05$ (Tukey's honestly significant difference HSD).

applied compaction pressure differently than the loaded, dump truck method potentially affecting only the upper soil layer. Senyk and Craigdallie (1997) found that soils responded differently to the use of various machinery and that water content at the time of activity was the critical characteristic in soil response. 
Table 7. Mean leaf area, and leaf dry weight measured in 2003 and 2004 showing responses to two pre-plant nitrogen (N) rates.

\begin{tabular}{lll}
\hline $\begin{array}{l}\text { Year: } \\
\text { Pre-plant } N \text { rate }^{\mathrm{z}}\end{array}$ & Leaf area $\left(\mathrm{m}^{2}\right)$ & Leaf dry weight $(\mathrm{g})$ \\
\hline 2003 & & \\
$\quad$ Standard rate $(\mathrm{n}=69)$ & $4.2 \pm 0.4 \mathrm{a}$ & $378 \pm 31 \mathrm{a}$ \\
$\quad$ Low rate $(\mathrm{n}=71)$ & $3.1 \pm 0.3 \mathrm{~b}$ & $288 \pm 27 \mathrm{~b}$ \\
2004 & & \\
$\quad$ Standard rate $(\mathrm{n}=37)$ & $13.2 \pm 1.2 \mathrm{a}$ & $1008 \pm 87 \mathrm{a}$ \\
$\quad$ Low rate $(\mathrm{n}=38)$ & $10.5 \pm 1.2 \mathrm{~b}$ & $787 \pm 78 \mathrm{~b}$ \\
\hline
\end{tabular}

${ }^{\mathrm{z}}$ Means \pm standard error followed by different letters indicate a significant difference within each biomass measure for pre-plant $\mathrm{N}$ treatments. Standard rate [H: 100 $\mathrm{mg} \cdot \mathrm{L}^{-1}$ ] or Low rate [L: $\left.25 \mathrm{mg} \cdot \mathrm{L}^{-1}\right]$, at the $P \leq 0.05$ (Tukey's honestly significant difference HSD).

The $\rho_{\mathrm{b}}$ readings achieved in the compacted treatments were similar to those found by other researchers to be restrictive to woody plant (Chiapperini and Donnelly 1978; Day and Bassuk 1994). Some researchers found that the same $\rho_{b}$ values in these NC plots were also restrictive to plant growth in their studies (Day et al. 1995). Alberty et al. (1984) found that early forsythia (Forsythia ovata Nak.) plants had a reduced root and shoot growth at a $\rho_{\mathrm{b}}$ of $1.2 \mathrm{~g} \cdot \mathrm{cm}^{-3}$, which is lower than the mean $\rho_{\mathrm{b}}$ of the $\mathrm{NC}$ soils in the current study.

Compaction activities reduce air-filled pore space and hydraulic conductivity because they disrupt the continuity of pore spaces and decrease overall pore size. Researchers found that mean AP in compacted soils was $7 \%$ lower than in the NC soils (11\%), and while significantly different, values around $10 \%$ are common for clay-type soils (Scott 2000). Poor aeration does not always provide a clear explanation of plant performance in compacted soils. Taylor et al. (1974) found that for cotton seedlings, low aeration porosity did not restrict root growth. Voorhees et al. (1975) found that root elongation rates decreased with an increase in bulk aeration porosity. Greenwood (1968, as cited in Eavis 1972) suggests that the "spatial distribution and area of the gas/liquid interface in the soil surrounding the roots" has a greater influence over root aeration than simply the reduction in the percent air-filled pore space due to compaction. Often, plants will develop shorter, thicker root systems in response to highly compacted or saturated soils, exhibiting low aeration porosity as a means of "adapting" to compacted soil and maintaining some level of growth (Eavis 1972; Voorhees et al. 1975; Shierlaw and Alston 1984).

$\mathrm{K}_{\mathrm{s}}$ in the compacted soils was $98 \%$ less than in the $\mathrm{NC}$ soil plots over the three years. Coutadeur et al. (2002) found that compaction caused by tractor-wheel tracks reduced $\mathrm{K}_{\mathrm{s}}$ by $40 \%$ when compared to soil between tracks, in the seedbed. In their work in north Germany, Gebhardt et al. (2009) found texture played an important role in $\mathrm{K}_{\mathrm{s}}$ in compacted soils. They found a reduction in $\mathrm{K}_{\mathrm{s}}$ of $60 \%$ in the clay loam soils, but no effect on $\mathrm{K}_{\mathrm{s}}$ due to compaction in the sandy and sandy loam soils. While results of the current study also show a decline in $\mathrm{K}_{\mathrm{s}}$ in compacted clay loams and silty-clay textures, the differences were of a much greater magnitude. Although many studies focus only on soil parameters, Donnelly and Shane (1986) found no reduction in growth of Quercus rubra (red oak), but Acer rubrum did show growth decreases over their five-year study with an increase in bulk density and a decrease in $\mathrm{K}_{\mathrm{s}}$. This may be related to a differential response to stress, in this case compacted soil, between the red oak and red maple species (Chapin et al. 1993; Grime 1977).
Ares et al. (2005) found no reduction in the growth of Douglas fir. In work done by Gomez et al. (2002), after similar compaction efforts, loamy soils had higher soil strength than clay soils. Compaction, however, had no effect on tree growth in the loamy soils, but in the clay soils biomass was reduced. This may be due in part to higher water content held throughout the growing season in the loamy soils. Studies by Donnelly and Shane (1986) and Ares et al. (2005) found that compaction increased available water content, whereas the study authors found a decrease (Table 1). These differences may be due to textural variation. Researchers fo the current study did find that NC soils had less water available at permanent wilting point (Table 1), which means that the compacted soils held water more tightly at the higher tension. Water held in compacted pores could then become available during portions of the growing season as weather and soil fauna affect density.

It is apparent that the hydraulic properties of soil, their temporal nature (Ares et al. 2005), and soil texture interact to determine restricting bulk densities for plant growth. In the clay-based soils in this study, hydraulic conductivity was significantly reduced due to compaction, and the higher density soils led to a reduction in aboveground biomass for the majority of the maples used. The results are similar to others that found variable responses across species and soil textural types. In a 1985 study, Pan and Bassuk found that Ailanthus altissima (tree-of-heaven) root growth was considerably more restricted in a sandy loam soil with a bulk density of $1.64 \mathrm{~g} \cdot \mathrm{cm}^{-3}$ than in mason sand with a bulk density of $1.67 \mathrm{~g} \cdot \mathrm{cm}^{-3}$. Ferree and Streeter (2004) found that in a siltloam, peat, and perlite soil mix with a bulk density of $1.5 \mathrm{~g} \cdot \mathrm{cm}^{-}$ ${ }^{3}$ certain cultivars of grape showed a reduction in leaf area and shoot length. In a sandy loam soil, avocado tree roots were limited to the upper few soil centimeters and clumped in soil areas with lower bulk densities (Abercrombie 1990). Day et al. (2000) found that the effects of compaction were mitigated when the soil was wet for Acer saccharinum (silver maple), but not for Cornus florida (flowering dogwood). The roots of silver maple were able to penetrate the compacted soil matrix when the water content was near saturation. However, the roots of flowering dogwood were not able to take advantage of the wet soils to elongate their roots, and showed dieback and in many cases death due to the high water content and limitations of the high bulk density. This may provide some explanation for the adaptability of bottomland species such as silver maple, Celtis occidentalis (hackberry), and Platanus occidentalis (sycamore) to compacted, urban soils.

Despite the small sample of excavated roots, researchers noted anecdotal root growth that supports some of these findings (Figure 3a; Figure 3b). In Figure 3a, roots of 'Celzam' grown in a compacted plot seem to have produced a large number of roots in the top few inches of the soil, directly beneath, and in the mulch. Roots escaped the original root ball mainly at the surface level. Figure 3b illustrates a broader spread of roots, with no distinct pattern evident when grown in uncompacted soil.

There was a significantly different response for the majority of biomass measures between cultivars. In general, most trees had reduced biomass growth as bulk density increased, but this was not consistent from year to year. Clearly, 'Celzam' Freeman maple out-performed all other cultivars, despite a reduced growth at higher bulk densities (Table 3; Table 4; Table 5; Table 6). 'Fairview Flame' was one of the best performing red maples when basing assessment on caliper growth, leaf area, and response to pre-planting $\mathrm{N}$ rates (Table 4; Table 5; Table 6). 


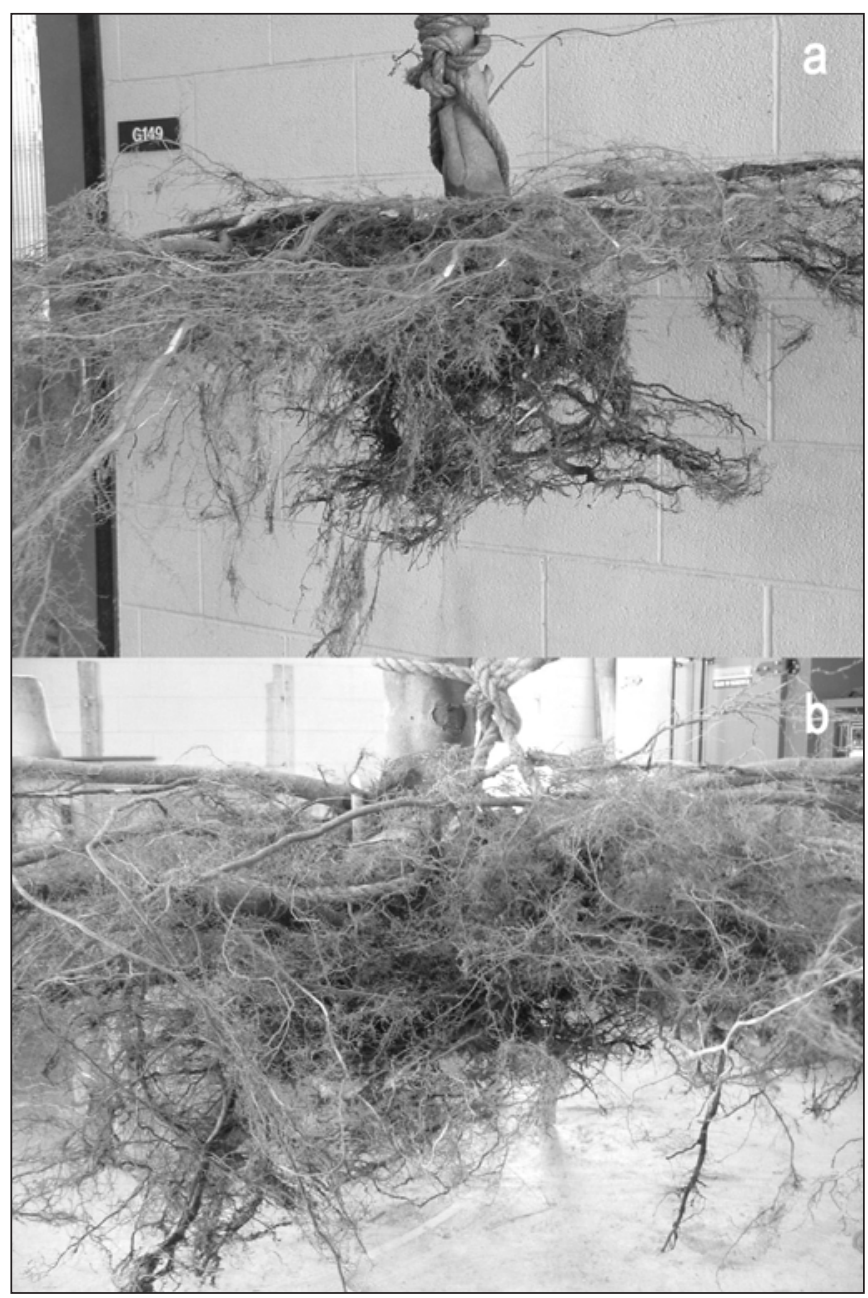

Figure 3. (a) Root system of 'Celzam' tree grown in C1 compacted plot clearly illustrating the location of the original root system within the $13 \mathrm{~L}$ pot. Much of the root system seems to be growing within the top $15 \mathrm{~cm}$ of the soil, just beneath the mulch, supporting findings from Gilman et al. (1987). (b) Root system of 'Celzam' tree growing in non-compacted soil plot illustrating a spreading root system, and no anecdotal evidence of root growth only beneath the mulch.

The majority of cultivars that received the standard rate of production nitrogen $\left(100 \mathrm{mg} \cdot \mathrm{L}^{-1} \mathrm{~N}\right)$ had larger LA, LDW, and larger SDW than trees treated with the low rate $\left(25 \mathrm{mg} \cdot \mathrm{L}^{-1} \mathrm{~N}\right)$ each year of the study, under all compaction treatments. Exceptions were 'Bowhall,' 'Morgan,' and 'October Glory,' which were unaffected by production nitrogen rate in any year. There was no interaction between $\mathrm{N}$ rate and soil treatment, therefore it is unlikely that the standard rate of pre-plant production $\mathrm{N}$ rate affects tree establishment in similarly compacted soils.

\section{CONCLUSIONS}

The most significant factor affecting growth response to compacted soil is plant species. Cultivar-to-cultivar differences dominated any overall differences between the Freeman and red maple groups in response to soil compaction $(P<0.0001$, Table $2)$, despite the close genetic relationship between Freeman and red maple. This variation among cultivars is consistent with other research that has explored growth rate, autumn color presentation, resistance to potato leafhopper, and wound response (Gallagher and Sydnor 1983), which all vary at the cultivar level for both red and Freeman maples (Townsend and Douglas 1998). 'Magnificent Magenta,' for example, may be an appropriate selection for small urban spaces where a slow growth rate may be appropriate. Anecdotally, the study authors found it an aesthetically pleasing tree with vibrant burgundy autumn color, despite compaction. 'Bowhall' trees also had a slow growth rate (lowest annual caliper growth on average), produced a noticeably ganglier crown (smallest leaf biomass measures) with a lighter green color (anecdotal observations), despite soil treatment compared with cultivars such as 'Magnificent Magenta' and 'Fairview Flame.' Although 'Bowhall' may be desirable for its slow growth, it is unlikely to be aesthetically acceptable to urban residents and may be less stress tolerant. The researchers have no explanation for 'Bowhall' trees' lack of response to compaction. All trees were treated similarly. If still a market favorite, this anomaly warrants further investigation; otherwise, the research suggests selecting other red maple cultivars for urban sites. 'Celzam' Freeman maple grew the fastest and though affected by compaction, it produced more biomass than other cultivars despite compaction, thereby increasing its chances of surviving establishment and growing normally if compaction alleviates over time. Both 'Celzam' and 'Fairview Flame' maples would be appropriate cultivars for claybased, compacted urban soils in the Midwest United States.

This research indicates leaf dry weight and leaf area increase when applying nitrogen at a rate of $100 \mathrm{mg} \cdot \mathrm{L}^{-1}$ compared to a lower rate of $25 \mathrm{mg} \cdot \mathrm{L}^{-1}$. The increase in leaf growth with the higher fertilization rate may be of benefit to trees whether growing in compacted or uncompacted clay-type soils; however, no significant increases were observed with the $100 \mathrm{mg} \cdot \mathrm{L}^{-1}$ rate for tree height and caliper growth or stem dry weight.

Acknowledgments: This research was supported by funds from the Kiplinger Endowment for Floriculture, a gift from the Ohio Nursery and Landscape Association and financial support from Dr. Daniel Struve. Salary and additional research support provided by state and federal funds appropriated to the Ohio Agricultural Research and Development Center, The Ohio State University. This paper is based on a portion of a dissertation submitted by B. Fair in partial fulfillment of the requirements for the Ph.D. degree in horticulture. We would like to thank A. McGill \& Son Wholesale Nursery, John Holmlund Nursery, LLC. and J. Frank Schmidt $\&$ Son Co. for donating the trees. We would also like to thank Dr. William Swallow (NCSU) for his invaluable statistical expertise, without which this manuscript would still be far from completion.

\section{LITERATURE CITED}

Abercrombie, R.A. 1990. Root distribution of avocado trees in a sandy loam soil as affected by soil compaction. Acta Horticulturae 275, Tropical and Subtropical Fruits. pp. 505-512.

Alberty, C.A., H.M. Pellett, and D.H. Taylor.1984. Characterization of soil compaction at construction sites and woody plant response. Journal of Environmental Horticulture 2:48-53.

Andrade, A., D.W. Wolfe, and E. Fereres. 1993. Leaf expansion, photosynthesis, and water relations of sunflower plants grown on compacted soil. Plant and Soil 149:175-184.

Ares, A., T.A. Terry, R.E. Miller, H.W. Anderson, and B.L. Flaming. 2005. Ground-based forest harvesting effects on soil physical proper- 
ties and Douglas-fir growth. Soil Science Society of America Journal 69:1822-1832.

Bengough, A.G., and I.M. Young. 1993. Root elongation of seedling peas through layered soil of different penetration resistances. Plant and Soil 149:129-139.

Blake, G.R., and K.H. Hartge. 1986. Bulk Density. pp. 364-367. In: A. Klute (Ed.). Methods of Soil Analysis, Part 1, Physical and Mineralogical Methods, 2nd Edition. ASA-Soil Science Society of America, Monograph 9. Madison, Wisconsin, U.S.

Boone, F.R., and B.W. Veen. 1994. Crop responses to soil compaction. pp. 237-264. In: B.D. Soane and C. van Ouwerkerk (Eds.). Soil compaction in crop production. Elsevier, Amsterdam.

Busse, M.D., R.F. Powers, C.J. Shestak, and A.W. Ratcliff. 2001. Glyphosate toxicity and the effects of long-term vegetation control on soil microbial communities. Soil Biology and Biochemistry 33:1777-1789.

Campbell, D.J., and J.K. Henshall. 1991. Bulk Density. pp. 367-397. In: K.A. Smith and C.E. Mullins (Eds.). Soil Analysis: Physical Methods. Marcel Dekker, Inc. New York, New York, U.S.

Chapin III, F.S., K. Autumn, and F. Pugmaine. 1993. Evolution of suites of traits in response to environmental stress. American Naturalist 142:578-592.

Chiapperini, G., and J.R. Donnelly. 1978. Growth of sugar maple seedlings in compacted soil. In: Proceedings of the Fifth north American Forest Biology Workshop. pp. 196-200.

Cook, A., C.A. Marriott, W. Seel, and C.E. Mullins. 1996. Effects of soil mechanical impedance on root and shoot growth of Lolium perenne L., Agrostis capillaris, and Trifolium repens L. Journal of Experimental Botany 47:1075-1084.

Coutadeur, C., Y. Coquet, and J. Roger-Estrade. 2002. Variation of hydraulic conductivity in a tilled soil. European Journal of Soil Science 53:619-628.

Day, S.D., and N.L. Bassuk. 1994. A review of the effects of soil compaction and amelioration treatments on landscape trees. Journal of Arboriculture 20:9-16.

Day S.D., N.L. Bassuk, and H.M. van Es. 1995. Effects of four compaction remediation methods for landscape trees on soil aeration, mechanical impedance and tree establishment. Journal of Environmental Horticulture 13:64-71.

Day, S.D., J.R. Seiler, and N. Persaud. 2000. A comparison of root growth dynamics of silver maple and flowering dogwood in compacted soil at differing soil water contents. Tree Physiology 20:257-263.

Donnelly, J.R., and J.B. Shane. 1986. Forest ecosystem responses to artificially indiced soil compaction. I. Soil physical properties and tree diameter growth. Canadian Journal of Forest Research 16:750-754.

Eavis, B.W. 1972. Soil physical conditions affecting seedling root growth. I. Mechanical impedance, aeration and moisture availability as influenced by bulk density and moisture levels in a sandy loam soil. Plant and Soil 36:613-622.

Ferree, D.C., and J.G. Streeter. 2004. Response of container-grown apple trees to soil compaction. HortScience 39:40-48.

Gallagher, P.W., and T.D. Sydnor. 1983. Variation in wound response among cultivars of red maple. Journal American Society for Horticultural Science 108:744-746.

Gebhardt, S., H. Fleige, and R. Horn. 2009. Effect of compaction on pore functions of soils in a Saalean moraine landscape in north Germany. Journal of Plant Nutrition and Soil Science 172:688-695.

Gee, G.W., and J.W. Bauder. 1986. Particle-size analysis. pp. 383-411. In: A. Klute (Ed.). Methods of Soil Analysis, Part 1, Physical and Mineralogical Methods, 2nd Edition. ASA-Soil Science Society of America, Monograph 9. Madison, Wisconsin, U.S.
Gilman, E.F., I.A. Leone, and F.B. Flower. 1987. Effect of soil compaction and oxygen content on vertical and horizontal root distribution. Journal of Environmental Horticulture 5:3-36.

Gomez, A., R.F. Powers, M.J. Singer, and W.R. Horwath. 2002. Soil compaction effects on growth of young ponderosa pines following litter removal in California's Sierra Nevada. Soil Science Society of America Journal 66:1334-1343.

Grime, J.P. 1977. Evidence for the existence of three primary strategies in plants and its relevance to ecological and evolutionary theory. American Naturalist 111:1169-1194.

Hook, D., and C. Brown. 1973. Root adaptation and relative flood tolerance of five hardwood species. Forest Science 19:225-229.

Iowa Dept. of Transportation. 2004. Determining standard proctor moisture density relationship of soils. Office of Materials. Materials I.M. 309.

Klute, A. 1986. Water retention: Laboratory methods. pp. 635-661. In: A. Klute (Ed.). Methods of Soil Analysis, Part 1, Physical and Mineralogical Methods, 2nd Edition. ASA-Soil Science Society of America, Monograph 9. Madison, Wisconsin, U.S.

Klute, A., and C. Dirksen. 1986. Hydraulic conductivity and diffusivity. pp. 687-733. In: A. Klute (Ed.). Methods of Soil Analysis, Part 1, Physical and Mineralogical Methods, 2nd Edition. ASA-Soil Science Society of America, Monograph 9. Madison, Wisconsin, U.S.

Liang, J., J Ahang, G. Y.S. Chan, and M.H. Wong. 1999. Can differences in root responses to soil drying and compaction explain differences in performance of trees growing on landfill sites? Tree Physiology 19:619-624.

Lipiec, J., and W. Stepniewski. 1995. Effects of soil compaction and tillage systems on uptake and losses of nutrients. Soil and Tillage Research 35:37-52.

Liu, I.W.Y., and L.J. Waldron. 1988. Root growth in coarse-textured soil under controlled confining pressure and matric potential. Annual Meeting. SSSA.

Lloyd, J. E., D. Herms, M. Rose, and J. van Wagoner. 2006. Fertilization rate and irrigation scheduling in the nursery influence growth, insect performance, and stress tolerance of 'Sutyzam' crabapple in the landscape. HortScience 41:442-445.

Masle, J., and J.B. Passioura. 1987. The effect of soil strength on the growth of young wheat plants. Australian Journal of Plant Physiology 14:643-656.

Maurya, P.R., and R. Lal. 1979. Effects of bulk density and soil moisture on radicle elongation of some tropical crops. pp. 339-347. In: R. Lal and D.J. Greenland (Eds.). Soil physical Properties and Crop Production in the Tropics. Wiley and Sons, Inc.

McLoda, N.A., and R.J. Parkinson. 1980. Soil Survey of Franklin County, Ohio. USDA, Soil Conservation Service. pp. 89-90.

Montagu, K.D., J.P. Conroy, and B.J. Atwell. 2001. The position of localized soil compaction determines root and subsequent shoot growth responses. Journal of Experimental Botany 52:2127-2133.

Pan, E., and N.L. Bassuk. 1985. Effects of soil type and compaction on the growth of Ailanthus altissima seedlings. Journal of Environmental Horticulture 3:161-167.

Perry, T.O. 1982. The ecology of tree roots and the practical significance thereof. Journal of Arboriculture 8:197-211.

Pittenger, D.R., and T. Stamen. 1990. Effectiveness of methods used to reduce harmful effects of compacted soil around landscape trees. Journal of Arboriculture 16:55-57.

Scott, H. Don. 2000. Soil Physics, Agricultural and Environmental Applications. Iowa State University Press. pp. 24.

Senyk, J.P., D. Craigdallie. 1997. Ground-based wet weather yarding operations in coastal British Columbia: Effects of soil properties and 
seedling growth. Information Report-Pacific Centre, Canadian Forest Service (BC-X-372) Victoria: Pacific and Yukon Region. 29 pp.

Shierlaw, J., and A.M. Alston. 1984. Effects of soil compaction on root growth and uptake of phosphorous. Plant and Soil 77:15-28.

Smiley, E.T., G.W. Watson, B.R. Fraedrich, and D.C. Booth. 1990. Evaluation of soil aeration equipment. Journal of Arboriculture 16:118-123.

Struve, D.K. 1995. Nitrogen, phosphorus and potassium recovery of container-grown red oak and blackgum seedlings under different fertilizer application methods. Journal of Environmental Horticulture 13:169-175.

Sydnor, T.D., and W.F. Cowen. 2000. Ohio Trees. Ohio State University Extension. pp. 166-167.

Tanney, J.B., and L.J. Hutchison. 2010. The effects of glyphosate on the in vitro linear growth of selected microfungi from a boreal forest soil. Canadian Journal of Microbiology 2:138-144.

Taylor, H.M. 1974. Root behavior as affected by soil structure and strength. pp. 27-291. In: E.W. Carson (Ed.). The Plant Root and Its Environment. Univ. Press of Va., Charlottesville.

Townsend, A.M., and L.W. Douglass. 1998. Evaluation of various traits of 40 selections and cultivars of red maple and Freeman maple growing in Maryland. Journal of Environmental Horticulture 16:189-194.

Unger, P.W., and T.C. Kaspar. 1994. Soil compaction and root growth: A review. Agronomy Journal 86:759-766.

Voorhees, W.B., D.A. Farrell, and W.E. Larson. 1975. Soil strength and aeration effects on root elongation. Soil Science Society of America Proceedings 39:948-953.

Watson, G.W., P. Kelsey, and K. Woodtli. 1996. Replacing soil in the root zone of mature trees for better growth. Journal of Arboriculture 22:167-172.

Whalley, W.R., E. Dumitru, and A.R. Dexter. 1995. Biological effects of soil compaction. Soil and Tillage Research 35:53-68.

Zablotowicz, R.M., K.N. Reddy, L.J. Krutz, and C. Accinelli. 2009. Soil depth and tillage effects on glyphosate degradation. Journal of Agriculture and Food Chemistry 57:4867-4871.

Barbara A. Fair (corresponding author)

North Carolina State University

154 Kilgore Hall

Campus Box 7609

Raleigh, North Carolina 27695, U.S.

bfair@ncsu.edu

James D. Metzger

The Ohio State University

Horticulture and Crop Science

310 B Kottman Hall

2021 Coffey Road

Columbus, Ohio 43210, U.S.

metzger.72@osu.edu

\section{James Vent}

The Ohio State University

Horticulture and Crop Science

Howlett Greenhouses HG, Building 297

680 Tharp Street

Columbus, Ohio 43210, U.S.

vent.1@osu.edu
Résumé. Cette étude évalue les effets de la compaction du sol sur la croissance de la partie aérienne de cultivars d'érable et compare également l'influence de deux taux différents d'azote appliqués en pré-plantation par rapport au degré de reprise et de croissance des arbres au sein de sols compactés. Huit cultivars d'Acer rubrum et d'Acer $\times$ freemanii communément employés ont été évalués. Lors de la production en pot, les plants ont reçu 25 ou $100 \mathrm{mg} / \mathrm{L}$ d'azote par fertigation à raison de deux fois par jour. Les arbres ont été plantés en champs dans des unités de sol non compacté (NC) avec une densité moyenne de $1,40 \mathrm{~g} / \mathrm{cm}^{3}$ ou au sein d'unités de sol compacté (C1) avec une densité moyenne de 1,60 g/ $\mathrm{cm}^{3}$. En 2002, nous avons sélectionné aléatoirement la moitié des unités compactées et avons appliqué un traitement additionnel au sol (C2). Une fois ce traitement complété, la densité moyenne du sol a atteint $1,55 \mathrm{~g} / \mathrm{cm}^{3}$. Les arbres qui poussaient dans les sols les plus denses avaient une biomasse aérienne mesurée $(\mathrm{p}<0,05)$ plus faible que ceux en sol non compacté $(\mathrm{NC})$. Il y avait des différences significatives $(p<0,0001)$ entre les cultivars; par exemple, 'Celzam' et 'Fairview Flame' avaient des valeurs en biomasse plus grandes que les autres cultivars lorsqu'ils étaient en sol compacté, mais la compaction affectait malgré tout leur croissance. L'engrais à un taux de $100 \mathrm{mg} / \mathrm{L}$ a permis d'accroître la masse foliaire sèche ainsi que la surface foliaire, mais n'a eu aucun impact sur la croissance en hauteur et en calibre ou encore la masse sèche de la tige.

Zusammenfassung. Diese Studie untersucht den Einfluss von Bodenverdichtung auf das oberirdische Wachstum von Ahorn-Kultivaren und vergleicht zwei Stickstoffgaben, die vor der Pflanzung aufgebracht wurden, bezüglich ihres Einflusses auf die Etablierung und Wachstum der Bäume, die in verdichtetem Boden gepflanzt wurden. Acht häufig verwendete Kultivare von Acer rubrum und Acer $\times$ freemanii wurden bewertet. Während der Container-Produktion erhielten die Pflanzen entweder 25 oder $100 \mathrm{mgL}^{-1}$ Stickstoff durch zweimalige Düngung pro Tag. Die Bäume wurden auf nicht-verdichtete (NC) Feldstandorte mit einer mittleren Körperdichte von $1,4 \mathrm{~g} \mathrm{~cm}^{-3}$ oder an verdichtete Standorte (C1) mit einer mittleren Bodendichte von $1,6 \mathrm{~g} \mathrm{~cm}^{-3}$ gepflanzt. In 2002 wählten wir zufällig die Hälfte der verdichteten Standorte und brachten eine zusätzliche Bodenbehandlung (C2) ein. Nach Ende der Behandlung betrug die Bodendichte $1,55 \mathrm{~g} \mathrm{~cm}^{-3}$. Bäume, die in dichteren Böden wuchsen, hatten deutlich weniger Biomasse über der Erde $(\mathrm{P}<0.05)$ als die Bäume in unverdichtetem Boden. Es gab einen signifikanten Unterschied zwischen den Kultivaren $(\mathrm{P}<0.0001)$; z. B. 'Celzam' und 'Fairview Flame' hatten höhere Biomassewerte als andere Kultivare, wenn sie in verdichteten Böden wuchsen als andere Kultivare, aber die Verdichtung zeigte doch einen Einfluss auf das Wachstum. Die $100 \mathrm{mgL}^{-1}$ Stickstoff-Gabe vergrößerte das Blatttrockengewicht und die Blattfläche, aber sie hatte keinen Einfluss auf die Höhe und Umfangzuwachs oder das Stammtrockengewicht.

Resumen. Este estudio evaluó los efectos de la compactación del suelo en el crecimiento de cultivares de maple, y comparó dos tasas de nitrógeno aplicadas pre-plantación, por su influencia en el establecimiento y crecimiento de árboles plantados en suelos compactados. Se evaluaron ocho cultivares de maple Acer rubrum y Acer $\times$ freemanii. Durante la producción en contenedor, las plantas recibieron entre $25 \mathrm{o} 100 \mathrm{mg} \cdot \mathrm{L}^{-1}$ de nitrógeno a través de ferti-irrigación, dos veces por día. Los árboles fueron plantados en parcelas no compactadas (NC) con densidad aparente media de $1.40 \mathrm{~g} \cdot \mathrm{cm}^{-3}$, o en parcelas compactadas $(\mathrm{C} 1)$ con una densidad media de $1.60 \mathrm{~g} \cdot \mathrm{cm}^{-3}$. En 2002, se seleccionaron aleatoriamente la mitad de las parcelas compactadas y se aplicó un tratamiento adicional al suelo $(\mathrm{C} 2)$. Al término de estos tratamientos la densidad aparente fue $1.55 \mathrm{~g} \cdot \mathrm{cm}^{-3}$. Los árboles que crecieron en suelos de altas densidades tuvieron significativamente más pequeñas biomasas aéreas $(\mathrm{P}<0.05)$ que los que crecieron en parcelas NC. Hubo una diferencia significativa entre los cultivares $(\mathrm{P}<0.0001)$; por ejemplo, 'Celzam' y 'Fairview Flame' tuvieron mayores valores de biomasa que otros cultivares cuando crecieron en suelos compactados, pero la compactación afectó aún el crecimiento. La tasa de $100 \mathrm{mg} \cdot \mathrm{L}^{-1}$ de nitrógeno incrementó el aérea foliar y su peso seco, pero no impactó la altura y el calibre o peso seco del tallo. 